\title{
COMPULSORY LIABILITY INSURANCE UNDER THE BRITISH ROAD TRAFFIC ACTS OF 1930 AND 1934
}

\author{
Francis Dé́K*
}

The increasing number of victims of automobile accidents has created in every country an urgent social problem. Clamor for legislative remedy, although by no means negligible, has been almost wholly ineffective in the United States. Only one of the 48 States of the Union-namely, Massachusetts-has passed legislation imposing on automobile owners the obligation of carrying liability insurance. ${ }^{1}$ Many European states have gone much further along this road. They have enacted statutes imposing on the owners or users of automobiles either a stricter liability than that of the common law (i.e. liability irrespective of fault or negligence), or an obligation to insure against liability (thus procuring a solvent debtor for the unfortunate victim) or both. Such legislation has been in force for years in Finland, Sweden, Norway, Denmark, Switzerland, Germany, Austria and Czechoslovakia. ${ }^{1 *}$ But the proponents of similar legislation in the United States could make but little impression on American lawyers and legislatures by pointing to the experience of these countries. We are prone to look with indifference, if not with distrust, upon the laws of Continental countries whose legal systems are built on a foundation different from that of our own. But because our law grew out of the same root as that of England, there may be less reluctance to consider what the British have done in adjusting their law to the changed conditions resulting from the appearance of the motor vehicle and the phenomenal growth of automobile traffic. Hence the salient features of the British legislation are of interest to American readers.

Agitation for legislative action in Great Britain to deal with various problems created by automobile traffic gained momentum in the late 1920's. The situation

- J.D., r925, University of Budapest; S.J.D., r927, Harvard University. Assistant Professor of Law, Columbia University School of Law. Adviser on foreign laws to the Committee to Study Compensation for Automobile Accidents. Member of Hungarian Delegation to several of the League of Nations Assemblies; Hungarian Delegate to World Economic Conference, London, 1933; member of Committee of Experts appointed by League of Nations Institute at Rome for the Unification of Private Law. Author of The Hungarian-Rumanian Land Dispute (1928), and of numerous articles on international law and comparative law in American and foreign periodicals; co-author with Philip C. Jessup of Neutrality: Its History, Economics and Law, Vol. I (1935).

${ }^{1}$ For a discussion of the Massachusetts law, see Blanchard, Compulsory Motor Vehicle Liability Insurance in Massachusetts, supra, p. 537.

2a See Deák, Automobile Accidents: A Comparative Study of the Law of Liability in Europe (I93I) 79 U. OF PA. L. REv. 27 . 
was indeed alarming. Traffic on the highways was regulated by the sadly out-dated Highways Act of 1896 and the Motor Car Act of 1903 . Both statutes were obviously framed to meet conditions wholly different from those prevailing after the war and the situation was more than ripe for reform. ${ }^{2}$ The number of accidents had increased by leaps and bounds. Proportionately, they were much greater than, for instance, in the United States. ${ }^{3}$ Naturally, there was growing dissatisfaction with the inadequacy of traffic rules, the unsatisfactory condition of highways for modern automobile traffic and, above all, with the unfortunate position of the increasing number of victims of automobile accidents, especially pedestrians. Their position was unfortunate because even if they succeeded through costly litigation in recovering a judgment at common law (i.e., by affirmatively proving the driver's negligence and, if need be, disproving contributory negligence on their part), they more often than not found their debtors insolvent.

With traditional thoroughness and surprising promptness, the British went about dealing with this situation. In 1928, a Royal Commission was appointed to examine the whole problem of transportation. On the basis of recommendations which the Commission embodied in its first report, after a careful survey, ${ }^{3{ }^{2}}$ the Government proposed a Bill which became the Road Traffic Act of 1930. 'The Act is a comprehensive statute providing for (a) the regulation of motor vehicles and traffic on roads (i.e., by classification of automobiles, licensing of drivers, driving offences and penalties therefor, etc.); (b) the protection of third parties against risks arising out of the use of automobiles; (c) amending the highway laws; and (d) the grant of power to local authorities to regulate public service vehicles.

We are at present concerned only with Part II (Sections 35-44) of the Act dealing with compulsory insurance, which was the major innovation brought about by the statute.

Section 35 of the Act makes it unlawful-under penalty of a fine up to $£_{50}$ or imprisonment up to 3 months and, subject to the court's discretion, disqualification for a year to obtain a license-to use or to permit another person to use an automobile unless there is in force an insurance policy in respect of the third-party risks specified in the Act. Public authorities are exempted from the obligation to insure and any person may deposit security of $£ 15,000$ in lieu of insurance. Section $3^{6}$

"See First Report of the Royal Commission on Transport, ("The Control of Traffic on Roads"), dated July 19, 1929. Cmd. 3365 , p. 3. "We cannot sufficiently emphasize the urgency involved in this Report. Legislation is greatly overdue. The present statute law on the subject [citing the two Acts referred to in the text], passed many years ago when motor traffic was in its infancy, is obsolete and many of its provisions are generally disregarded. ... The sooner an obsolete law, which is clearly no longer applicable to present circumstances and which public opinion refuses to support, is repealed or amended, the better."

s According to statistics quoted during the debate of the Road Traffic Bill of 1930 in the House of Commons, there were in 1929 in New York City 671,000, in London about 200,000 cars registered cxclusive of motor-cycles. The fatal accidents statistics for the same year show 1291 in New York and $2_{282}$ in London. Hansard, Parliamentary Debates (Commons) 5th Ser., Vol. 235, pp. 1248-49. In comparing these figures, account should be taken of the fact that the population of the two cities are about the samc and that New York is a more congested area than London.

sa See the Report cited supra note 2.

20 \& 2 I GEO. 5, c. 43. 
specifies that the policy must be issued by an "authorized" insurer (i.e., a company or underwriter complying with the requirements of the amended Assurance Companies Act, 1909) and must cover any liability which the insured may incur on account of the death of or bodily injury to a person caused by or arising out of the use of the car on the road.

It is to be noted that the insurance covers only personal injury and not damage to property. The Government felt that the great difficulties involved in the introduction of the compulsory insurance system would have been unduly increased by attempting to include property damage. Under Section 36 , the insurance need not cover personal injuries suffered by persons in the insured's service in the course of their employment or by persons gratuitously transported in the car. The insured must be given a "certificate of insurance" without the production of which a license will not issue for the use of the car on the road (Section 39).

The most important safeguard which the statute intended to give to third parties is contained in Section 38. This section provides that the claims of third parties shall not be affected by any conditions in a policy except those which relate to something which the policy requires to be done or omitted after the occurrence of the event giving rise to a claim under the policy. The apparent consequence of this is to wipe out practically the effects of breach of conditions after the accident on the claims of third parties. The insurer's liability to the insured was sought to be safeguarded by paragraph (4) of Section $3^{6}$ providing that the insurer shall be liable to the insured for any risk covered by the policy, notwithstanding the provisions of any prior law. But it should be pointed out that as judicially construed the statute has left in full force those rules of the common law which enable an insurer to repudiate a policy obtained by misrepresentation or by non-disclosure of a material fact. As experience shows, insurance companies have frequently relied upon these rules to avoid liability under the policies. ${ }^{5}$

To complete the picture of measures whereby the British Parliament sought, in 1930, to better the position of victims of automobile accidents, reference should be made to another statute, passed shortly before the Road Traffic Act. The Third Parties (Rights Against Insurers) Act, $x 930,{ }^{8}$ gave to the injured person a right of direct action against the insurer in case of the insured's insolvency. In such a case the rights of the insured against the insurer on account of liability incurred by the former are transferred to and vested in the injured third party (Section $x$, paragraph I). The Act further provides that no agreement made between the insurer and the insured, after liability to a third party has been incurred, nor any waiver, assignment or payment made to the insured shall defeat or affect the rights transferred to the third party (Section 3).

\footnotetext{
'See the criticism of the Act, after four years of operation, in papers read by Messrs. Barry O'Brien and Sebag Cohen before the Annual Provincial Meeting of the Law Society in September, 1934, in (1934) 178 LAw Times 231-38.

${ }^{\circ} 20$ \& 21 GEO. 5, c. 25.
} 
Despite the manifold criticisms which have been directed at the Road Traffic Act since it came into force, it represented at the time of its enactment a great step toward remedying a most unsatisfactory situation. The introduction of compulsory insurance, particularly, was a progressive step toward a more equal distribution of the cost society must pay for technical progress. Since it was an innovation, there was considerable opposition to this measure by both insurance companies and automobile owners and users. The Government realized from the outset the great difficulties which compulsory insurance involves but, to quote the words of the Government's spokesman for the Bill, "on the balance, we decided that we would face the difficulties and deal with an intolerable injustice which ought not to be allowed to exist." The necessity of some like measure was conceded even by the opponents of the Bill and the insurance companies themselves promised their coöperation to make the scheme workable and agreed not to raise premiums, at least for the time being. Due to this cooperation of private business, the Government could introduce the compulsory insurance scheme without reserving for itself the power of rate-fixing. Perhaps the most remarkable feature of the British Act is that this form of social insurance has been accomplished without any of the concomitants which are commonly believed inevitably to accompany such measures-namely, the administration of the insurance scheme, or, at least, the fixing of premiums, by the state itself. In fact, the insurance companies lived up to their agreement and no serious criticism has been levelled against this aspect of the Act. Premiums are today, after six years, still fixed by the private insurer and complaints on the part of the motoring public on account of the burden of paying for the insurance are not vociferous.

It was in other respects that the $193^{\circ}$ Act was subjected to criticism and was finally amended in 1934 . One of the main criticisms concerned the insurance protection provisions. As has been pointed out above, the seemingly strict language of the Act proved in practice to have left too many loop-holes through which insurers who wanted to do so could escape payment to injured third parties. It was felt that the Act did not, in practice, give the public the protection "which it is entitled to receive, and which it was the intention of the Legislature that it should receive." Taking into consideration the short-comings of the 1930 Act as they appeared in the light of experience, the Government proposed and secured passage of an amending statute which became the Road Traffic Act of $1934{ }^{\circ}$ So far as these insurance protection provisions are concerned the principal change sought by the 1934 Bill was summed up by the Minister of Transport (Mr. Oliver Stanley) as follows:

"In the case where a policy has been obtained by any mis-statement at the present moment the insurance company can repudiate the policy, because of that mis-statement, and leave it to the injured person, by a very laborious process, first of all suing the insured person, then bankrupting him and, finally, obtaining a right of action against the insur-

The Minister of Transport (Mr. Herbert Morrison) in the debate during the second reading of the Road Traffic Bill on February 18, 1930. Hansard, Parliamentary Debates (Commons) 5th Scr., Vol. 235, p. 1203 .

${ }^{8}$ See the paper of Mr. O'Brien, supra note $5 . \quad{ }^{\circ} 24 \& 25$ Geo. 5 , C. 50. 
ance company. Only then can the injured person find out whether the insurance company are entitled to void that policy or not. Under the new provisions, the company will become liable on their policy as soon as the injured person secures a judgment, if the car was being used within the terms of the policy. It will then be for the insurance company, if they wish to repudiate, to get the declaration from the court saying that they are entitled so to do, and they will only be able to get that declaration on the ground of non-disclosure of material facts. It shifts the onus in this case from the injured person to the insurance company."10

In accordance with the Government's proposal, Section ro of the Act, as finally passed, imposes a duty on the insurer to pay any judgment obtained by an injured third party against the insured even if the insurer would be entitled to avoid or cancel the policy as against the insured. The relieving clauses still leave, however, a somewhat generous loophole to the insurer to escape this duty. He is permitted to avoid the policy, even as against third parties, (a) if he has not received notice of the suit within seven days after its commencement; (b) if before the accident, from which the claim arose, the policy has been cancelled; (c) if in an independent action commenced within 3 months after institution of the suit for damages, he obtains an adjudication that apart from any provision contained in the policy hei is entitled to avoid it on the ground that it was obtained by non-disclosure of a material fact, or by misrepresentation. ${ }^{11}$ While the avoidance of an insurance contract on these grounds has been recognized in the English common law, the statute now places upon the insurer the burden of proving such facts in a separate action rather than raising them as a defense in an action on the contract. The omission of a requirement for a clause permitting avoidance on these grounds is relatively unimportant since they were grounds for repudiation at common law. It is more important to note that the insurer's ability to repudiate was further restricted by Section 12 of the 1934 Act which denies effect to conditions concerning the age or physical or mental condition of the driver, the condition of the car, the number of persons that the vehicle may carry, the time at which or the areas within which the car is used, and the horse power or value of the car. This provision was inserted because of the insurer's frequent resort to such clauses in order to escape liability.

This is, briefly, the status of the law at present in Great Britain. Although progressive the legislation cannot be called revolutionary. The remedy it affords to injured third parties is only partial because the statutes deal only with one aspect of the plight in which the victim of an automobile accident finds himself-namely, the tort-feasor's financial responsibility. Neither act touches upon the question of legal liability; recovery is still left conditioned upon the ability of the injured person to prove affirmatively the driver's negligence and disprove his own contributory negligence. Anyone who ever had anything to do with an automobile accident either

${ }^{10}$ Hansard, Parliamentary Debates (Commons) 5th Ser., Vol. 288, p. 178.

${ }^{11}$ Italics added. Par. 5 of $\$$ ro defines material facts (non-disclosure of which entitles the insurer to avoid the policy) as "of such a nature as would influence the judgment of a prudent insurer in determining whether he will take the risk, and, if so, at what premium and on what conditions." 
as a witness or a participant or with an accident litigation will readily admit that this is a burden not easy to sustain. ${ }^{12}$ As we have seen, the guaranty to the victim that he will receive payment is by no means hole-proof. Yet, it cannot be denied that the situation as compared with that which existed prior to $193^{\circ}$ is materially better. What is still more important is the fact that the imperfections of the statutes are frankly recognized both by the executive and the legislative branches of the British Government as shown by the promptness with which the 1930 Act was amended in I934 in order to eliminate the most objectionable features of what was obviously experimental legislation. It may not be amiss to point out that this experiment in social legislation has been accomplished without in any way relinquishing faith in and adherence to the traditional British respect for individualism as a foundation of British democracy. There were no hues and cries of "socialization" merely because a step had been taken to remedy an "intolerable injustice." No doubt, Great Britain will continue to improve its laws as practical experience points to further inadequacies. May we not hope that some of our more forward looking state legislatures will attempt, as Massachusetts has done, to solve what is indeed a major problem of modern mechanized society?

\footnotetext{
${ }^{20}$ In 1932 Lord Danesfort introduced a bill in the House of Lords proposing to abolish the common law rule of negligence and of contributory negligence in automobile accident litigations. After a lengthy but instructive debate (see Hansard, Partinmentary Debates (Lords) Vol. 84 , p. 547) the bill was referred to a Select Committee and finally passed, by the Lords in May, r934, as the Road Traffic (Compensation for Accidents) Bill. It rests somewhere in the Commons.
} 